Volume 11 Number 1, January-March 2017: pp. 1-14 Copyright (c) 2017 FIAT JUSTISIA. Faculty of Law, Lampung University, Bandarlampung, Lampung, Indonesia.

ISSN: 1978-5186 | e-ISSN: 2477-6238.

Open Access: http://jurnal.fh.unila.ac.id/index.php/fiat

Fiat Justisia is licensed under a Creative Commons Attribution 4.0 International License, which permits unrestricted use, distribution, and reproduction in any medium, provided the original work is properly cited.

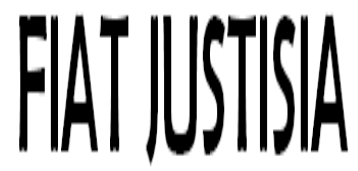

\title{
Legal Issues in Sharia Pawn Gold Practice in Indonesia
}

\author{
Lastuti Abubakar \\ Faculty of Law, University of Padjadjaran \\ lastutiabubakar@yahoo.com \\ Tri Handayani \\ Faculty of Law, University of Padjadjaran \\ t212h@yahoo.com
}

\begin{abstract}
In the past few years, there is a trend of applying Islamic concept in Indonesia's economic system, and it has implications for the existing legal system whereby new legal system should accommodate the changes. One of the institutions that use both conventional and shari'a system in Indonesia is pawning as an alternative financing mechanism, particularly for micro and consumption sectors. In practice, the function of pawning as a financing instrument has shifted into investment by continuously doing pawning and buying. As a result, people who need fund for financing are not facilitated. The current regulation has allowed this practice for banks, pawn shops, and financial institutions to offer pawn gold that is not for financing activity but investment activity. Therefore, it raised a question whether this activity is complying with the shari'a principles. What kind of regulations that can make the function of pawning back to its original purpose as a financing mechanism. This study uses a normative juridical approach by using secondary data from the legal resources, with a specification of research methods using descriptive analysis whereas data are qualitatively described. The findings from this study reveal that the practice of pawning gold in Indonesia has not been fully consistent with the pawning function, therefore; it requires appropriate regulation so that the original function as the alternative financing for households and small, medium enterprises (SMEs) is not shifted to gold investment vehicles. Pawning gold is expected to be complementary to the businesses and households regarding financing that cannot be fulfilled by the banks and other financial institutions.
\end{abstract}

Keywords: Pawn Gold, Legal Pawning, Shari'a 


\section{A. Introduction}

The presence of Islamic banking institutions in Indonesia, is the need for the Muslims in Indonesia, to ensure their financial transactions based on shari'a. ${ }^{1}$ Pawnshops in Indonesia show the increasing trend from time to time. It is characterized by the number of funds that are distributed by PT. Pegadaian to the customers for the short-term financing for the micro and small and medium enterprises.

Nevertheless, it still must be recognized that the current pawning is used for consumption. The percentage of consuming pawning is still high compared to productive pawning. For example, BRI Syariah just reported for 11 percent for the financing in productive enterprises. ${ }^{2}$ As additional problems in practice of pawn financing, it is not only that pawnshops are still not optimal as productive financing resources but also that they still use a dual system in line with the enforcement of legal dualism in the economic activity of conventional and shari'a systems. ${ }^{3}$

It is proved by a rise of shari'a pawning gold (Rahn), that is recognized as a modification from the conventional pawning, and this can be considered as deviated from the objectives and principles of the shari'a system. The practice of shari'a system in Indonesia's pawning gold was introduced by Bank Jabar Banten Syariah (BJBS) in 2004. During its development, a shari'a gold pawn is demanding product for all small and large Islamic banking in Indonesia. Bank Rakyat Indonesia Syariah (BRISyariah), as one of the Islamic banks that favors Islamic pawn products, has increased 100 percent since Islamic pawning business was launched in 2009. Likewise, Bank Negara Indonesia Syariah (BNI-Syariah) within three months (July to September 2011) since its launch in 2010 rose from 5.12 percent to 12.86 percent. In June 2012, BNI Syariah recorded the outstanding pawn of gold at 250 billion rupiahs meanwhile Bank Syariah Mandiri (BSM) per November 2012 recorded gold-backed financing to reach the target of 800 billion rupiahs ${ }^{4}$. Data issued by Bank Indonesia as the banking authority showed a significant increase in pawn gold from 1136 accounts with the amount of around 20 billion rupiahs in March 2004, which was up to 283,795 accounts with nominal amount approximately 4.1 trillion rupiahs in December 2012.

One of the contracts that are commonly used in Indonesia is qardh contract. In October 2012, data from Bank Indonesia (Indonesian Central

1 Muhammad Sjaiful, "Urgensi Prinsip Proporsionalitas pada Perjanjian Mudarabah di Perbankan Syariah di Indonesia". Halrev Journal of Law, 1(2), (2015), p. 228.

2 BRI Syariah, "Merancang Gadai Emas Produktif, Sharing, Meluruskan Niat Gadai Emas Syariah", 61 (6), (2012), p. 1.

${ }^{3}$ Lastuti Abubakar, "Implications of Economic Activity Shari'a Law Economic Development in Indonesia", Legal Review. 1 (2), (2010). 
Bank) showed the instrument financing for Islamic Banks and Islamic Business Units using qardh contracts achieved nominal of Rp. 11.195 billion, from total contracts including mudharaba, musharaka, Murabaha, salam and so forth with the total value of Rp.135.581 billion. This amount is declining compared to that in the previous year with the total value of $\mathrm{Rp}$. 12.937 billion. However when compared with 2010 which total value is $\mathrm{Rp}$. 4.731 billion, contracts of qardh for 2011 and 2012 show better performance. Graphic 1.1 below shows development of the qardh contract in Indonesia period 2012.

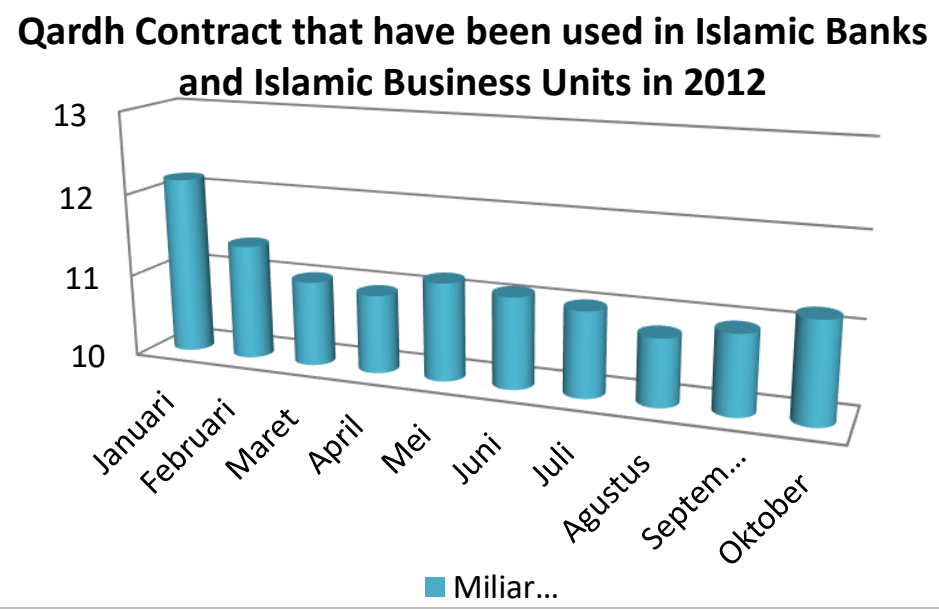

On the other hand, the rapid development of shari'a pawning gold, caused concern among banking analysts, that the practice of pawning gold has potentially decreased the functions and roles of Islamic banking as an intermediary, in particular in financing productive enterprises in the real sector. Bank Indonesia as the regulator has given a pledge to the pawnshops in order not to dominate finance in Islamic banking. This concern becomes a background issuance of Circular Letter of Bank Indonesia (Surat Edaran Bank Indonesia/SEBI) No: 14/7/ DPbS, dated February 29, 2012, subject to qardh products gold backed of shari'a bank and shari'a business unit.

This concern arises because shari'a pawn gold should stick on the essence of shari'a principle which is to help people to get funds quickly for venture capital. Types of financing such as pawn gold are needed by most business people in Indonesia whereby around 99.9 percent or around 51.3 million business people in Indonesia are within the range of micro and small medium enterprises level (Ministry of Cooperatives and Small and Medium Enterprises, 2012). The existence of shari'a pawning gold will be the top choice for micro-business since they are categorized as a non-bankable business to get financing and loans from the bank. Barriers for micro- 
business cannot fulfill the requirement of financial analysis or bank loans as stipulated in the Banking Act No. 7/1992 as amended by Banking Act. No.10/1998 about banking and Law No.21/2008 about Shari'a Banking.

In practice, shari'a pawning gold begins to leave the essence of shari'a principles and gets more used to take advantage as much as possible through the practice of speculative repeating pawning. ${ }^{4}$ Another concern comes from banking practices, which also see the potential for shari'a pawning gold as a promising product. But in practice, banks have not run shari'a pawning gold by Islamic principles (shari'a compliance). The practice of repeating pawning (top-up) and Murabaha (sale and purchase) of gold in installment is believed to alter the function and purpose of pawning gold. If shari'a pawning gold is not regulated properly, then it is not possible to weaken the banking intermediary function. It could potentially slow down economic growth and movement in Indonesia. Bank Indonesia sees very rapid progress in pawning gold as a result of the issuance of fatwa No. DSN: 79/DSN-MUI/III/2011 dated March 8, 2011, regarding qardh using customer funds, which could potentially increase the risk for Islamic banking

This study aims to examine and analyze the regulation of pawning gold in Indonesia and offers to pawn gold to reform regulations to fit the function and purpose of pawning gold as an alternative Islamic term financing for productive enterprises, especially for individuals and micro business.

This study uses a normative juridical approach which focuses on secondary data in the form of primary legal materials laws and regulations and material objects literature relating to the research, while the specification is a descriptive, analytical study in which the results of the analysis are described in the description. Analysis of the data used in this study is qualitative juridical using the power of abstraction and interpretation of the law, for further manifested in the descriptions.

\section{B. Analysis And Discussion}

\section{Shari'a Gold Pawn Legal System in Indonesia}

One of the Islamic products that are currently offered by many financial institutions and banks in Indonesia is pawning gold shari'a. Not only PT. Pegadaian but Islamic banks also offer this product. Shari'a pawning gold has become one of the top products of Islamic banking in Indonesia as a differentiator from products of conventional banks. As part of the activities of Islamic economics, the main principles of Islamic economics should certainly be considered in regulating pawn gold. Compilation of

\footnotetext{
${ }^{4}$ Without a Name, “Aligning Intention Gold Pawn Sharia”, Sharing, 61 (6), (2012).
} 
Islamic economic laws does not explicitly define shari'a principles, therefore the formulation in article 1 paragraph 12 of Law No.12/2008 on Islamic Banking can be used as a reference; it is stated: "The shari'a principles is the principle of shari'a Islamic law in banking activities based on fatwa issued by agency that has the authority in issuing shari'a fatwa.". Asutay ${ }^{5}$ in his paper mentioned that the regulation of shari'a pawning gold should pay attention to three aspects as follows: First, the principle of shari'a Islamic law, which rests on three pillars namely aqeedah, shari'a and akhlaq. This is what distinguishes the Islamic economy from the conventional one. Islamic economics emphasizes the element of belief (aqeedah), to maintain a certain character (not to be deceptive or speculate) and comply with shari'a.

Second, the principle of Islamic law is then transformed into a fatwa that issued by competent authorities. In formulating a fatwa, clerics refer to all sources of Islamic law such as Al-Quran, Al-Hadith, ijma, qiyas, istishan, istihlab, and so forth. Third, the fatwa issued by Indonesia's Cleric Council (Majelis Ulama Indonesia) through the National Shari'a Board. In addition to Islamic principles, the practice of pawning gold in Indonesia is set out in the Second Book of Civil Law (Civil Code/KUHPerdata) chapter 1150 to 1160, known as interest-based conventional pawning. According to the regulations in Indonesia, there is a dualism in the legal system in Indonesia namely conventional and shari'a pawning.

Furthermore, the gold pawn mechanism refers to the National Shari'a Council (DSN) No.25/DSN-MUI/IIII/2002 about rahn and fatwa DSN MUI No. 26/DSN-MUI/III/2002 about gold rahn. Rahn is defined as "holding the goods as collateral for the debt." Referring to the fatwa, shari'a pawns and Islamic banks get profit from the administrative fee from redemption certificates of pawning. In the implementation, there is no standardization fee for gold rahn between Islamic banks due to \no detail explanation in the fatwa.

It is the main reason why gold shari'a pawn is not complying with hari'a anymore. As a part of the economic activities of sharia, the Islamic gold pawn has some prohibited activities such as: riba as the illegal additional revenues, bathil, in exchange transactions that is not similar in quality, quantity and delivery time $f a d l$, or in a transaction that requires customers to repay their loan more than their principal due to passage of time, and nasi'ah, gambling transaction is banned due to its uncertainty and speculation. Ghararas is a transaction that unclear about the physic, the ownership and the existence of the object or the object is not available

\footnotetext{
${ }^{5}$ Mehmet Asutay, An Introduction to Islamic Moral Economy. North East England: Durham Islamic Finance Summer School, Durham University, (2012).
} 
during transaction unless it is regulated in shari'a principles. Haram is a transaction that the object is forbidden based on shari'a. Zalim is the transaction that is an injustice for another party. However, besides those prohibitions, shari'a gold pawn should be interpreted as wealth transfer and wealth creation. ${ }^{6}$

Based on the restrictions above the practice of shari'a gold pawn should be free from riba. Based on empirical facts in Indonesia, along with the arising of the gold price, public demand for the gold pawn is increasing. The pawn that is originally started as a financing instrument is shifting into an investment instrument. Based on the survey from pawnshops and Islamic customers, there is shifting in the paradigm that makes the gold pawn a way to earn another gold. It is known as gardening gold, and this is considered not complying with shari'a and turns the gold pawn into speculation activities.

Amir Nuruddin, Professor of Economics Faculty of Sharia, from IAIN in North Sumatra asserts: "pawning gold on Islamic banking has essentially to help people who are in short-term having financial difficulties, so they need a loan (al-qardh) with gold as collateral (gold rahn) as well as pay for the gold deposit in the bank with ijara contract. Adiwarman Karim, a consultant and expert on Islamic economics in Indonesia, confirms that the practice of pawning gold is not in line with original purposes of the activity of pawning gold and does not comply with a fatwa from National Shari'a Council.

Based on the understanding of shari'a pawning gold, it should be recognized that the purpose of shari'a pawning is to move the real economy. On the other hand, gold investment resulting in the gold accumulation that will potentially freeze the economy due to retention of funds flow to the community. Therefore, it is necessary to have an understanding and precise mechanism that makes shari'a gold pawn is not shifted to gold investment practice. Pawning gold is an alternative Islamic financing based on shari'a principles, while gold investment aims to generate profit.

There are some weaknesses of pawning gold regulation in Indonesia which led to the practices of pawning gold into investment activities, as follows: first, there is no limit of time for doing pawning. Thus the pawning can always be extended continuously. Second, a fatwa from DSN-MUI No.77/DSN-MUI/2010 that allows purchasing (Murabaha) gold in installments. Based on the fatwa above, some banks have done innovation in Islamic products by allowing customers to buy the gold in installment and then repeatedly pawn their gold without limitation. In this case, the gold loses its role as a financing function and shifts into speculative investment

\footnotetext{
${ }^{6}$ Paul, Mills \& John, Presley. Islamic: Finance Theory and Practices.
} 
function. It is a contrast to the original function of pawning, which is to obtain financing using moving goods as collateral, and when it reaches its maturity, it should be redeemed. Economically, the pawnshop has functioned as the economy mover on a small scale.

In early 2012, Bank Indonesia issued a Circular Letter of Bank Indonesia (SEBI) about qardh backed gold products, which nature is an appeal to all Islamic Banks, Islamic business units and rural sharia banks in Indonesia that qardh backed gold products (gold pawn) must have the following characteristics:

1. The fund is intended to be used for short-term funds to finance additional working capital or short-term for micro and small groups.

2. The contract that has to be used is qardh contract (to increase loan provided by sharia banks or Islamic business units), rahn contract (for the binding of gold as collateral for the loan fund), and ijarah contract (for the binding of storage utilization and maintenance services of gold as collateral for loans)

3. Fees that can be charged to customers are administrative costs, insurance costs and maintenance of the gold as collateral for loans.

4. Sources of funding may come from the capital, retained earnings, and third-party funds.

5. The customer must clearly state the purposes of the fund on the application form.

6. Gold that will be submitted as collateral qardh backed the customer should already own gold at the time of apply for financing.

The Legal problem arises since the Circular Letter of Bank Indonesia is not a legal product in the hierarchy of legislation, it is only considered as a guideline. On the other hand, fatwa by DSN No. 77/DSN/2010 that allows the purchase of pawning gold in installment based on the hierarchy of legislation is in the higher position than Circular Letter of Bank Indonesia. The legal power of Circular Letter of Bank Indonesia is weak; hence it is necessary to make regulations equivalent to Fatwa DSN or PBI which are the products of legislation

Under the Circular Letter Of Bank Indonesia which regulates the qardh backed gold products, Islamic banking and Islamic business units that will offer qardh products must meet the following requirements:

1. Apply for a license to Bank Indonesia

2. Have Standard Operating Procedures written adequately, including the implementation of risk management?

3. Total portfolio of qardh backed gold for Islamic banks must have minimum requirements of 20 percent of the total financing provided or 150 percent of bank capital (capital adequacy); meanwhile for Islamic business units, must not exceed 20 percent from the total financing given. 
4. Total maximum amount of financing is Rp. 250.000.000,- for each customer, with a maximum period of 4 months and can be renewed maximum two times. Customers of small, medium enterprises (SME) can be given the maximum amount of financing for Rp. 50.000.000,- with a maximum period of 1 year in installments every month and cannot be extended.

5. Total financing should be compared with the value of the collateral (financing to value) which should be maximum 80 percent of 100 grams of gold average market selling price and buyback price by PT. ANTAM (Persero) Tbk.

6. Islamic banks or Islamic business units must declare transparently in both written and orally to the customer about characteristics of products (such as features, risks, benefits, costs, requirements and if there is a dispute resolution) and the rights and obligations of the customer including event collateral execution gold.

Circular Letter of Bank Indonesia is a guideline for the authority to regulate the return of shari'a pawning gold to match the objectives and purposes.

\section{a. Some Legal Issues in Practicing Shari'a Pawning Gold in Indonesia 1) Re-Pawning (Top Up)}

Regulation of pawning gold is not comprehensive giving a possibility to do re-pawning in practice and getting worst by allowing the purchase of gold using installment based on a fatwa by DSN No.77/DSN/2002. The first Islamic bank that practices gold pawn is BRI Syariah, and it was widespread. Within a year, BRI Syariah was able to reach 12 percent of the total financing or approximately worth 600 billion rupiahs. Re-pawning, mechanism of redemption that should be one of the essential elements of the pawning, however, does not occur. Pawning period is typically within four months, and at the maturity date, the customer should return the loan and pay the ujrah, so that the gold can be collected. But with the possibility of repawning (top up), customers do not collect the gold, but their pawn is back, and so on. Thus, what happens in practice is it is no longer a pawn but a continuous loan.

Furthermore, the fatwa that allows buying gold in installments is exacerbating the practice of pawning gold. Practically, the gold will be purchased by installment; then the gold will be pawned back. As a result, pawning gold transaction in Islamic banking grows rapidly. Adiwarman Karim worries a loose regulation in pawning gold system based on this fatwa. He concerns about the use of public funds in the practice of Murabaha gold, considering the case of default in financing, will result in 
the deposit guarantee agency (Lembaga Penjamin Simpanan-LPS) suffering the consequences.

Regulation should not accommodate shari'a gold pawn practices that lead to investment. Besides that it is contrary to the shari'a principle, it is necessary to avoid that those funds from pawnshops or Islamic banks will flow to those who do not need financing. Here, the pawnshop lost its role as an economy-productive activity but shifted to meet the excessive consumption for a particular community. It is feared to have an impact on the stability of the Indonesian economy.

\section{2) Combination of Several Covenants in the Pawning that is not Considered Shari'a-Compliance}

One important distinction between shari'a gold pawn and conventional gold pawn lies in the agreement that underlies them. In a conventional pawn, pawnshops or financial institutions such as banks take advantage of the rate established at the beginning of the agreement, while the Islamic shari'a pawning gold forbids charging interest in the economic activity. Therefore, the use of covenants in practice shari'a gold pawn becomes important. To date, there is still a view in the community that shari'a gold pawn is an adaption of the conventional products that are labeled shari' $a$. It cannot be avoided due to several things: the dualism legal system in economic activity in Indonesia, demand for the conventional product is high and human resources in the banking and financial institutions that dominate Islamic relatively are not numerous and evenly, as well as there is still lacking people understanding of Islamic product. Shari'a gold pawn practice in Indonesian banking, pawning mechanism based on the combination of several contracts. Irham Fahreza Annas in his research finds that there are some joint agreements made under the document signed by the client such as the first combination consisting of two versions, namely ${ }^{7}$ : loan agreement with a pawn (Rahn) or, in the framework of qardh Rahn contracts and ijara contracts. The second combination is qardh contracts, Rahn contracts, and ijara contracts. The third combination is gold pawn financing, whereby in the document it does not mention the three names of original contract such as qardh, Rahn, and ijara.

According to Islamic principles, basic legal questions related to the merger agreement concern about the meaning of qardh in the mechanism of gold pawn. Referring to the fatwa by DSN No: 19/DSN-MUI/IV/2010 about Al-Qardh sets that qardh is a loan contract to the customer who is obligated to return the funds he receives to the worksheet at a time agreed upon by the

\footnotetext{
${ }^{7}$ Irham Fachreza Anas, Questioning Gold Pawn iB: Criticism and Repair Gold Pawn Islamic bank. Jakarta: the Islamic Association of Indonesian Economists, (2012).
} 
Islamic Financial Institutions (Lembaga Keuangan Syariah) and customer or loans given to customer (muqtaridh) in need. Furthermore, a fatwa by DSN No: 19/DSN-MUI/IV/2010 set that "Al-Qardh gives customers extra (donation) as long as it is voluntary and not defined in the contract.

The merger agreements have the potential to violate prohibitions that avoid the contract qardh: firstly, to get benefit from qardh contract secondly is to combined Qardh contract with another contract. The essence of Qardh contract will be lost if there is implied benefits arising from other contracts. This is contrary to the purpose of clarity of purpose of the contract. Therefore, it is necessary to find the concept of usage-contract agreement that is not prohibited.

Other legal issues are about charging fees to clients in the practice of shari'a pawning. According to the combination of 3 joint agreements used in shari'a practice pawn, it can be concluded that the benefits of Islamic banking or pawnshop come from fees charged to the customer in the form of administrative cost gold pawn, gold pawn objects insurance costs and the cost of maintenance pawn objects. In practice, the imposition of administrative costs can be done in several ways, namely: first, establishing a nominal administration fee per weight in gold and is charged at the time of realization of shari'a gold pawn; second, setting with a certain nominal administration fee for all the gold pawn financing imposed upon realization of financing, and the letters are not allowed to charge administration because it is included in the cost of care and maintenance.

Furthermore, the cost of insurance (premium) is typically charged to bank on customers as with attempts to shift risk in the event of something beyond the control of the bank or the customer (force majeure). In practice, insurance claims will be included in a clause of the agreement. Another expense is the cost of maintenance of pawn object, namely some fees charged to customers for objects stored in bank or pawnshop. The mechanism used in a bank based on a particular term is ten to15 days, while every 10 to 15 days, the bank will make the cost of maintenance as bank receivables, which will be calculated at the time of payment as the cost of maintenance.

Legal issues arising in the practice of gold pawn in Indonesia can be solved with a comprehensive set back about shari'a gold pawn by National Shari' $a$ Council (DSN), so the gold pawn will be back in line with shari'a's objective. The regulation established should be able to provide solutions to the problems that arise in the practice of shari' $a$ gold pawn, as follows:

\section{Re-Pawning Restrictions}

Re-pawning (top up) no longer meets the purpose and function of shari'a gold pawn: it can even be said that pawning without time limitation 
can potentially endanger the banking system. In the event of arising in the gold price, then the customer will likely continue tore-pawning to get a margin, so it is not clear whether the margin is shari'a compliant or not? Banks cannot control the use of public funds due to customer's pawning gold again, so the purpose of a gold pawn as alternative financing is not valid; it has turned into an investment. This condition is further away from the principles of shari' $a$ as the mechanism of investment funds should come from customers, not from public funds managed by the bank. On the other hand, a fatwa by DSN No: 77/DSN-MUI/2002 allowing Murabaha in buying gold in installments needs to be reviewed. This particular fatwa becomes a trigger for the increasing of shari'a gold pawn because gold pawn customers will pay the installment, and then re-pawn it

\section{Guidelines for the Use of Multiple Covenants in Shari'a Gold Pawn}

Prohibition for combined agreement in the contract can be circumvented by pawning gold adhering to the principles of clarity of intent agreement. Practice in combining agreement under shari'a gold pawn (Rahn) is the form of the agreement between qardh and ijara contracts that obscure the purpose of Rahn contract; therefore, it necessary to make a guideline to all banks and pawnshops on how to use multiple covenants but still complying with shari'a. The concept of multi-contract (murakkab contract) can be a solution for the merger of agreement that is not shari'a compliance. Murrakab contract is an agreement between two parties to carry out a contract that contains two or more such contracts with lease purchase, grant, power of attorney, qardh, shirkah, etc. so all the legal consequences of the contract are collected as well as all rights and obligations arising seen as a whole that cannot be separated, as the legal. ${ }^{8}$

\section{Administration Fee Transparency in Gold Pawn Mechanism}

The imposition of administrative charges on customers in the Islamic pawn mechanism is regulated by specifying the shari'a compliance rate calculation, to avoid the practice of pawning gold usury practices or improper advantage. Imposition of maintenance and care are considered excessive if the customer is also burdened with insurance premiums. The first reason is that the bank carries the insurance for the benefit of the bank because the object of a pawn is under the control of the bank. Second, the definition of maintenance and deposit is interpreted keeping the security and safety of goods. Therefore, the imposition of premiums and the cost of

\footnotetext{
${ }^{8}$ Ibid.
} 
maintenance would be unjust for the customers. It is contrary to maqasid al shariah. ${ }^{9}$

\section{Conclusion}

\section{Conclusion}

Based on the results, legal issues in the practice of shari'a gold pawn in Indonesia can be summarized as follows: First, gold pawn is one of the alternative Islamic financing systems for small-scale productive companies that have potential to be developed in order to support the economy of Indonesia, in fact, that 99.9 percent or 51.3 millions of businesses in Indonesia are in a small micro level that requires easy financing;

Second, regulation of gold pawn in the form of Islamic fatwa, is not yet comprehensive in the sense that it is not guaranteed in gold pawn practices will be shari'a compliance. The weakness of this regulation provides an opportunity for practitioners and the pawn institutions to innovate in shari'a gold pawn products that are increasingly outpacing the purpose and function of the shari'a. The form of the innovation that has potential to be out of shari'a principle is the practice of top-up (re-pawning), gold purchase in installment, the combined agreement and the imposition of administrative costs, maintenance cost as well as premiums insurance that is not transparent.

Third, the authorities of the financial service and DSN-MUI have not formulated a comprehensive regulation; thus the practice of gold pawn has not got a solid legal foundation. Also, supervision of sharia gold pawn practices has not been followed by strict punishment for Islamic banks and financial institutions. Based on these reasons, it is necessary to make new comprehensive regulations of sharia gold pawn that captures all the rules.

\section{Suggestion}

To overcome some of the weaknesses in the practice of gold pawn, it is recommended that:

First, it is necessary to realign comprehensive shari'a gold pawn and accommodate the aims and objectives of shari'a gold pawn as alternative financing.

Second, the DSN-MUI with financial services authority immediately issue a fatwa on re-pawning restrictions, guidelines about the combination of agreement and fatwa about a charge cost that is shari' $a$ compliance.

\footnotetext{
${ }^{9}$ Asutay, Mehmet. Loc. Cit.
} 
Third, strong political will from the government continuously improves a reliable resource to fruitful of proficient Islamic economist as well as socialize with the community about shari'a gold pawn.

\section{A. Books}

\section{Bibliography}

Bank Indonesia. (2006). Kamus Istilah Keuangan dan Perbankan Syariah, Jakarta: Direktorat Perbankan Syariah.

Bank Indonesia. (2011). Bahan-bahan Terpilih dan Hasil Riset Terbaik, Jakarta: Bank Indonesia.

Hulwati. (2009). Ekonomi Islam-Teori dan Praktik dalam Perdagangan Obligasi syariah di Pasar Modal Indonesia dan Malaysia. Jakarta: Ciputat Press.

Mills Paul \& Presley John, Islamic: Finance Theory and Practices.

Pusat Perencanaan Pembangunan Hukum Nasional. (2011). Draft Naskah Akademik Rancangan Undang-undang Tentang Pergadaian. Jakarta: Kementerian Hukum dan HAM RI.

Sudin Haron, Wan Nursofiza, Wan Azmi. (2009). Islamic: Finance And Banking System. Kuala Lumpur: Mc Graw Hill Malaysia Sdn Bhd.

\section{B. Legislations}

Code of Civil law.

Decree of the Minister of Cooperatives and Small and medium-sized.

Government Regulation Number 51 on 2011 of Change of Legal Entity Become Pawnshop Company Limited.

Republic of Indonesia Law No. 10 on 1998 of Amendment to Law Number 7 on 1992 of Banking.

Republic of Indonesia Law No. 19 on 2003 of State-Owned Enterprises.

Republic of Indonesia Law No. 9 on 2011 of Amendment to Law Number 9 on 2006 of Warehouse receipt.

National Shari'a Board Fatwa Number 25/DSN-MUI/III/2002 on Rahn (Shari'a pawn).

National Shari'a Board Fatwa Number 26/DSN-MUI/VIII/2002 on Rahn of gold.

National Shari'a Board Fatwa Number 68/DSN-MUI/III/2002 on Rahn Tasjily.

Republic of Indonesia Number: 01/Per/M.KUKMII/2010.

\section{Journal and Article}

Bank Indonesia, "Posisi Pinjaman Rupiah yang diberikan Bank Umum dan BPR Menurut Kelompok Bank dan Lapangan Usaha“, tatistik Ekonomi Keuangan Indonesia, www.bi.go.id, January $11^{\text {th }} 2012$. 
Kementerian Koperasi dan Usaha Kecil dan Menengah RI" Rencana Strategis Kementerian Koperasi Dan Usaha Kecil dan Menengah Republik Indonesia Tahun 2010-2014”, www.pegadaian.go.id Januari $11^{\text {th }}, 2012$.

Muhammad Sjaiful, "Urgensi Prinsip Proporsionalitas pada Perjanjian

Mudarabah di Perbankan Syariah di Indonesia", Halrev Journal of Law, 1 (2), (2015)

Irham Fachreza Anas, Menyoal Gadai Emas iB : Kritik dan Perbaikan

Gadai Emas bank Syariah, The Indonesian Association of Islamic Economist, Jakarta, (2012).

Lastuti Abubakar,'Implikasi Aktivitas Ekonomi Syariah Terhadap Perkembangan Hukum Ekonomi di Indonesia“, Legal Review, 1 (2), (2010).

No Name, "Meluruskan Niat Gadai Emas Syariah", Sharing, 61 (6), (2012). Mehmet Asutay, " An Introduction to Islamic Moral Economy ", Durham Islamic Finance Summer School, (2012)

D. World Wide Web

http://www.republkak.co.id/berita/ekonomi/syariah-ekonomi/12/07/09/m6vv qz-bni-syariah-bukukan-gadai-emas-rp250-m.

http://keuangan.kontan.co.id/news/gadai-emas-bank-syariah-mandiri-gand eng-bprs/2013/01/03 